\title{
Influence of the aerosol solar extinction on photochemistry during the 2010 Russian wildfires episode
}

\author{
J. C. Péré ${ }^{1}$, B. Bessagnet ${ }^{2}$, V. Pont ${ }^{3}$, M. Mallet $^{3}$, and F. Minvielle ${ }^{1}$ \\ ${ }^{1}$ Laboratoire d'Optique Atmosphérique, Université Lille 1, 59655 Villeneuve d'Ascq, France \\ ${ }^{2}$ Institut National de l'Environnement Industriel et des Risques, Parc Technologique Alata, 60550 Verneuil en Halatte, France \\ ${ }^{3}$ Laboratoire d'Aérologie, Observatoire Midi-Pyrénées, 14 Avenue Edouard Belin, 31400 Toulouse, France
}

Correspondence to: J. C. Péré (jean-christophe.pere@ univ-lille1.fr)

Received: 17 November 2014 - Published in Atmos. Chem. Phys. Discuss.: 10 March 2015

Revised: 18 September 2015 - Accepted: 22 September 2015 - Published: 2 October 2015

\begin{abstract}
In this work, impact of aerosol solar extinction on the photochemistry over eastern Europe during the 2010 wildfires episode is discussed for the period from 5 to $12 \mathrm{Au}-$ gust 2010, which coincides to the peak of fire activity. The methodology is based on an online coupling between the chemistry-transport model CHIMERE (extended by an aerosol optical module) and the radiative transfer code TUV. Results of simulations indicate an important influence of the aerosol solar extinction, in terms of intensity and spatial extent, with a reduction of the photolysis rates of $\mathrm{NO}_{2}$ and $\mathrm{O}_{3}$ up to $50 \%$ (in daytime average) along the aerosol plume transport. At a regional scale, these changes in photolysis rates lead to a $3-15 \%$ increase in the $\mathrm{NO}_{2}$ daytime concentration and to an ozone reduction near the surface of 1$12 \%$. The ozone reduction is shown to occur over the entire boundary layer, where aerosols are located. Also, the total aerosol mass concentration $\left(\mathrm{PM}_{10}\right)$ is shown to be decreased by $1-2 \%$, on average during the studied period, caused by a reduced formation of secondary aerosols such as sulfates and secondary organics (4-10\%) when aerosol impact on photolysis rates is included. In terms of model performance, comparisons of simulations with air quality measurements at Moscow indicate that an explicit representation of aerosols interaction with photolysis rates tend to improve the estimation of the near-surface concentration of ozone and nitrogen dioxide as well as the formation of inorganic aerosol species such as ammonium, nitrates and sulfates.
\end{abstract}

\section{Introduction}

For several years, it has been well recognized that air pollution of gaseous and particulate origin can have adverse health effects (Miller et al., 2012; Beelen et al., 2014). In consequence, efficient air pollution control strategies have now become a challenge for environmental policies. In the context of air quality monitoring, the exceedance of certain thresholds of pollutant concentrations is a criterion often used by authorities of a country to protect people from air pollution exposure. In general, the exceedance of these thresholds is evaluated from an air quality numerical forecast such as in France where the regional chemistry-transport model CHIMERE (Menut et al., 2013) is used in the French national air quality forecasting and monitoring system known as PREV'AIR (Honoré et al., 2008). Photochemical pollutants (ozone, secondary aerosols, ...), which are formed from photo-dissociation of precursors such as nitrogen dioxide $\left(\mathrm{NO}_{2}\right)$ and volatile organic compounds (VOCs) (Jenkin and Clemitshaw, 2000), are of particular interest for air quality monitoring (Honoré et al., 2008) due to their negative impacts on both environment and human health (Amin, 2014; Hunova et al., 2014).

The key parameter that governs the photo-dissociation of photochemical precursors in the atmosphere is the photolysis rate, which mainly depends on the available actinic flux (Seinfeld and Pandis, 2006). Aerosols are known to have large influence on the available actinic flux by interacting with solar radiation in the ultraviolet-visible wavelengths (J. Li et al., 2011; G. Li et al., 2011; Lou et al., 2014). For example, Wai and Tanner (2010) showed, by using a combination of 
remote sensing observations and chemical-transport model, that aerosol solar extinction could lead to a 7-32\% reduction in maximum ozone concentration over Hong Kong during highly polluted days. Also, G. Li et al. (2011) highlighted, with WRF-CHEM modeling experiments, that changes in photolysis rates due to the presence of particles led to a decrease of about, respectively, 2-17 and 5-6\% in daytime ozone and secondary aerosol (nitrate, secondary organics) concentrations over Mexico City during the 2006 Megacity Initiative: Local and Global Research Observations (MILAGRO) campaign.

To reduce computational time for operational purposes, one major characteristic of air quality modeling platforms is that impacts of aerosols and clouds on solar radiation are often taken into account as simplified attenuation factors when evaluating the photolysis rates (Honoré et al., 2008; Menut et al., 2013). However, Real and Sartelet (2011) highlighted that simplified parametrization of aerosol impact on photolysis rates could tend to worsen air quality model performance in simulating ozone and particulate concentration, especially under highly polluted environments.

The aim of the present study is to implement, in the chemistry-transport model CHIMERE, an explicit representation of the alteration of photolysis rates by aerosols and discuss the impact in terms of modeled ozone budget and the formation of secondary aerosols at the regional scale. We focus on a major fire event that occurred in Russia during August 2010 as its episode was characterized by important concentrations of primary and secondary aerosols and large concentrations of ozone, especially over this specific region (Zvyagintsev et al., 2010; Konovalov et al., 2011; Popovicheva et al., 2014). Also, the study of Chubarova et al. (2012) clearly shows that, during this specific wildfire episode, the aerosol optical thickness over the Moscow region was more than three times larger than the one observed during typical August conditions over the period 2001-2010. This suggests that, even if anthropogenic aerosols are present over the studied region, the contribution of smoke aerosols during this specific event is very large. Then, this case study represents an excellent opportunity to discuss how aerosol solar extinction, especially biomass burning particles, can affect photochemistry. Fires can affect atmospheric chemistry in several ways. They emit primary gaseous pollutants (such as $\mathrm{CO}, \mathrm{OH}, \mathrm{NO}, \mathrm{NO}_{2}$ and volatile organic compounds) that can react in the atmosphere to form ozone and other pollutants (Turquety, 2013). They also released aerosols that can directly affect air quality - or indirectly by acting as a medium in complex heterogeneous reactions (Slade and Knopf, 2013; Nie et al., 2015). Finally, they can affect the intensity of solar radiation, which in turn can affect the photochemistry of the atmosphere. The latter impact is the subject of the present study.

The approach is based on an online coupling between the regional model CHIMERE, extended by an aerosol optical module (Péré et al., 2010), and the Tropospheric Ultraviolet and Visible (TUV) radiation model (Madronich and Flocke, 1998). In this methodology, the aerosol optical thickness, single scattering albedo and asymmetry parameter are first modeled by CHIMERE using an aerosol core-shell mixing hypothesis, as in Péré et al. (2009, 2010). This mixing approach has been previously used by Péré et al. (2014) to study the 2010 Russian wildfires direct radiative forcing and its feedback on the regional atmospheric dynamics. Results indicate that it can give a good representation of the absorption properties of particles during this specific period. For a second time, aerosol optical properties are used as inputs in the radiative transfer code TUV to evaluate the impact of aerosol short-wave solar extinction on photolysis rates and the formation of ozone and secondary particles. The advantage of such methodology is the use of two specific state-of-the-art models to explicitly simulate the interaction of physicallychemically resolved aerosols with the actinic flux and the associated impact on modeled photolysis rates and photochemistry. Section 2 describes the configuration of each model as well as the development of their online coupling. In Sect. 3 we discuss modeled regional changes in the near-surface concentrations of $\mathrm{NO}_{2}, \mathrm{O}_{3}$ and secondary aerosols over Russia induced by modifications of photolysis rates by smoke aerosols during August 2010. Finally, conclusions and perspectives of future works are given in Sect. 4.

\section{Methodology}

\subsection{Description of the CHIMERE model}

\subsubsection{Aerosol module}

CHIMERE is a state-of-the-art 3-D chemistry transport model that calculates the concentrations of numerous gaseous and particulate pollutants (Vautard et al., 2001; Menut et al., 2013). The dynamics and gas phase parts of the model are regularly improved (Menut et al., 2013) and their documentation can be downloaded at http://www.lmd. polytechnique.fr/chimere/. In this work, the CHIMERE domain has a $30 \mathrm{~km}$ horizontal resolution and ranges from 43.40 to $63.20^{\circ} \mathrm{N}$ in latitude and from 18.70 to $57.30^{\circ} \mathrm{E}$ in longitude. The aerosol part is described by Bessagnet et al. (2004) and is composed of 10 chemical species: sulfates, nitrates, ammonium, primary organic and black carbon (OC and BC), secondary organic aerosols (SOAs), sea salt, natural and anthropogenic dust and water. The evolution of aerosols is described with an eight-bin size distribution (from about $40 \mathrm{~nm}$ to $10 \mu \mathrm{m}$ in diameter) and includes the main physical processes such as nucleation, coagulation, condensation/evaporation, adsorption/desorption, wet and dry deposition and scavenging.

Anthropogenic emissions of gaseous and particulate origin come from the EMEP database. Concerning OC and BC emissions, the inventory of Junker and Liousse (2008) has 
been used. Natural soil dust is dynamically produced within the domain according to the methodology of Vautard et al. (2005). SOA formation is represented through oxidation processes of relevant precursors of biogenic and anthropogenic origin and gas particle partitioning schemes (Bessagnet et al., 2008). VOC and NO emissions from vegetation are calculated using the Model of Emissions of Gases and Aerosols from Nature (MEGAN) (Guenther et al., 2006). Aerosols and gases emitted by wildfires affecting Russia during 2010 are taken into account following the work described and validated by Kaiser et al. (2012). It consists in the assimilation of the fire radiative observations from the Moderate Resolution Imaging Spectroradiometer into the Global Fire assimilation System combined with the use of specific combustion rate and emission factors to estimate biomass burning emissions. More information on the methodology as well as a validation study for the 2010 Russian wildfires episode can be found in Kaiser et al. (2012).

CHIMERE is forced at these boundaries by monthly climatologies, calculated over the 2000-2004 period, of the main gases and particles provided by the MOZART (Horowitz et al., 2003) and LMDzT-INCA global chemistrytransport models (Hauglustaine et al., 2004), respectively. The evaluation study of Péré et al. (2014) showed that the fire inventory of Kaiser et al. (2012) used in this work combined with the CHIMERE model well captured the evolution of the Russian fire plume during the studied period, suggesting a low influence of these boundary conditions. Also, CHIMERE is offline driven by the Weather Research and Forecasting model (WRF) at a $30 \mathrm{~km}$ resolution. The version 3.1 is used in this study with the same configuration as in Péré et al. (2011). It has 27 vertical levels from $40 \mathrm{~m}$ to about $20 \mathrm{~km}$ and includes the following parametrizations: the WRF single-moment five-class scheme of Hong et al. (2006) for the microphysics module, the Kain-Fritsch cumulus parametrization (Kain, 2004), the NOAH land surface module of Chen and Dudhia (2001) and the Yonsei University planetary boundary layer scheme (Hong et al., 2006; Hong, 2007).

\subsubsection{Modeling aerosol optical properties}

The calculation of optical properties of particles is the prerequisite for the evaluation of their impacts on photolysis rates and photochemistry as they provide information on how aerosols will interact with the actinic flux. In that sense, we developed a numerical scheme dedicated to calculate aerosol optical properties from aerosol concentrations, size distribution and chemical composition modeled by CHIMERE. A complete description of this optical module is presented in the work of Péré et al. (2010). To compute the complex refractive index of a particle, the hypothesis of a core-shell mixing has been chosen with a core of primary species (BC, OC and dust) surrounded by a shell of secondary ones (sulfates, nitrates, ammonium, secondary organics) and sea salt and water. This mixing choice is supported by recent studies giving evidence of coatings of secondary particles on black carbon aerosols over Europe (Vester et al., 2007; McMeeking et al., 2011). Also, such mixing has been shown to correctly reproduce the absorbing properties of aerosols during the 2010 Russian wildfire episode (Péré et al., 2014). For each size bin, a volume average procedure is used to calculate the refractive indices of the core and the shell (Lesins et al., 2002) which are then used as inputs in the Mie algorithm for $n$-layered spheres of $\mathrm{Wu}$ and Wang (1991) to calculate the scattering and absorption coefficients. It should be noted that the volume of the core and the shell can vary during the simulation in function of the different physical processes influencing aerosol population. The optical properties of the total aerosol distribution needed in radiative transfer modeling, such as the aerosol optical thickness (AOT), single scattering albedo (SSA) and asymmetry parameter $(g)$, are calculated as in Wu et al. (1996).

A detailed evaluation of the optical module for the 2010 Russian wildfire episode by using different sets of measurements is presented by Péré et al. (2014). Only a summary is given here. Figure 1 presents the temporal evolution of the AOT between 5 and 12 August 2010 modeled by CHIMERE at $500 \mathrm{~nm}$ and measured by the Terra MODIS (Moderate Resolution Imaging Spectroradiometer) satellite sensor at $550 \mathrm{~nm}$. The simulated $850 \mathrm{hPa}$ wind is also indicated. As shown by the $850 \mathrm{hPa}$ wind fields, meteorological conditions were characterized by an important anticyclonic system over central Russia which favored the recirculation and accumulation of pollution from intensive wildfires and anthropogenic origin (Witte et al., 2011). MODIS observations highlight this intense particulate pollution episode with AOT $(550 \mathrm{~nm})$ above 1 over large areas and values up to 4 along the transport of the aerosol plume. This plume was advected in the anticyclonic flow from the source region (east of Moscow) towards Moscow and the northern part of the area (6-10 August) and back to the east on 1012 August. Although the maximum AOT value observed by MODIS is underestimated by CHIMERE, we can see that the model is able to reproduce the main aerosol plume features in terms of transport and intensity during this specific period, with a spatial correlation of $0.4-0.8$ and a normalized mean bias of -(15-40)\% depending of the day. Some minor discrepancies between CHIMERE and MODIS can be seen, such as local AOT underestimations within the intense plume or some overestimations near the source region. These AOT biases may induce local under or overestimation of the aerosol solar extinction simulated by CHIMERE and its potential impact on the photolysis rates discussed in relation to Figs. 3 and 4. The altitude of transport was shown to be below $5 \mathrm{~km}$ and comparisons between CHIMERE and CALIOP show good consistency, as discussed in further detail in what follows in relation to Fig. 8. Figure 2 indicates that the transport of this intense aerosol plume over Moscow between 6 and 10 August 2010 was recorded in the AOT measure- 

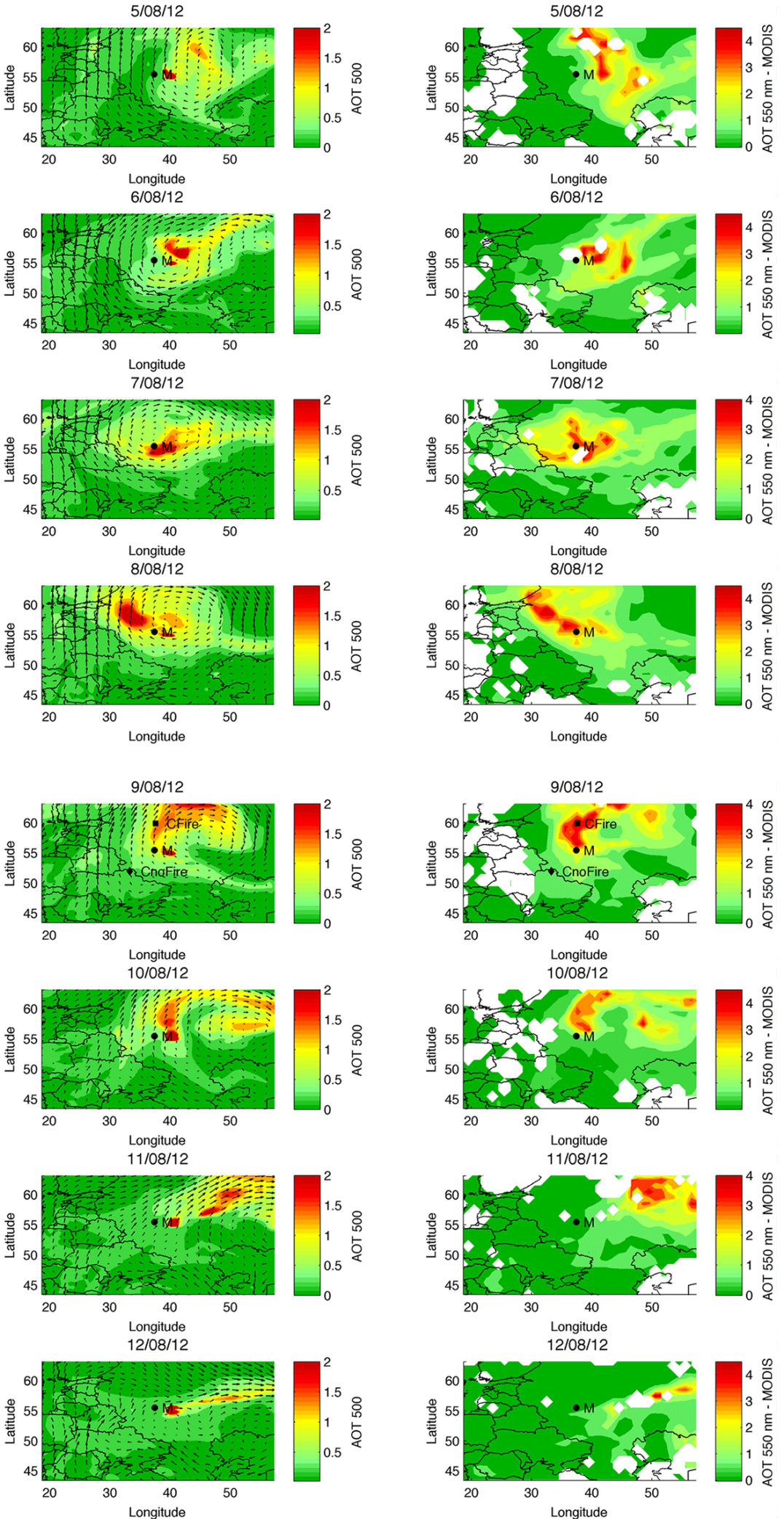

Figure 1. Geographic distribution of the AOT between 5 and 12 August 2010 modeled by CHIMERE at 500 nm (left panel) and measured by the Terra MODIS (Moderate Resolution Imaging Spectroradiometer) satellite sensor at $550 \mathrm{~nm}$ (right panel). The simulated $850 \mathrm{hPa}$ wind is also indicated. $\mathrm{M}$ is the localization of Moscow and CFire and CnoFire are the localizations of the two CALIOP profiles used in Fig. 8. 
ments of the Moscow AERONET station. We can see that a large enhancement of the particulate pollution is detected over Moscow when the plume overpasses the area, with an AERONET AOT $(440 \mathrm{~nm})$ ranging from 0.56 on 5 August to 2-4 between 6 and 10 August. Then AOT decreases to moderate values $(0.4-0.7$ at $440 \mathrm{~nm})$ on $11-12$ August when the intense aerosol plume leaves the region. CHIMERE simulates rather well the temporal evolution of the AOT over Moscow during this period with biases from -53 to $8 \%$, except for the 6 and 10 August. For these two days, the model underestimation is of $60-75 \%$ due to some model deficiencies in simulating the transport of the intense aerosol plume over Moscow. During the study period, Péré et al. (2014) showed that organics species are the dominant part of the aerosol composition simulated by CHIMERE over Moscow with relative contributions of 8-67 and 16.5-75\% for, respectively, primary organic carbon and secondary organic aerosols. OC is the major chemical species between 5 and 10 August (43-67\%) while SOA dominates at the end of the period $(71-75 \%)$ when the aerosol plume moves away from Moscow. These elevated proportions of organic carbon are the result of large OC and VOC (volatile organic compound) emissions (mainly from wildfires with also an anthropogenic contribution) combined with an important photochemistry favored by persistent sunny conditions. BC particles are present in a much lower fraction (0.4-0.8\%). This important contribution of scattering organic aerosols lead to high SSA modeled over Moscow throughout the period, with values of 0.97 (between 300 and $1000 \mathrm{~nm}$ ), in good agreement with AERONET measurements over Moscow (0.950.96 between 440 and $1020 \mathrm{~nm}$ ). Such elevated SSA associated to large proportion of organic species is supported by recent studies. High SSA values (0.95 in the visible spectrum) have been measured during this specific fire episode by Chubarova et al. (2012) and are typical of peat fires and smoldering conditions. Also, Popovicheva et al. (2014) highlight, with physical-chemical measurements, that the aerosol composition over Moscow during the 2010 fire episode is dominated by organic species with a low fraction of black carbon. Globally, the comparisons between aerosol simulation and measurement data highlighted the ability of the model to give an appropriate representation of the aerosol size distribution and scattering/absorption properties (Péré et al., 2014), which is a prerequisite to evaluate its influence on photolysis rates and the formation of photochemical pollutants.

\subsection{Description of the TUV model}

TUV is a widely used state-of-the-art radiative transfer model developed at the National Centre for Atmospheric Research (Madronich and Flocke, 1998). In this study, we used the version 4.6 of the code (released in March 2009) freely available at the website: http://cprm.acd.ucar.edu/Models/ TUV/. The model calculates the actinic flux and photolysis rates of a large number of photochemical species.

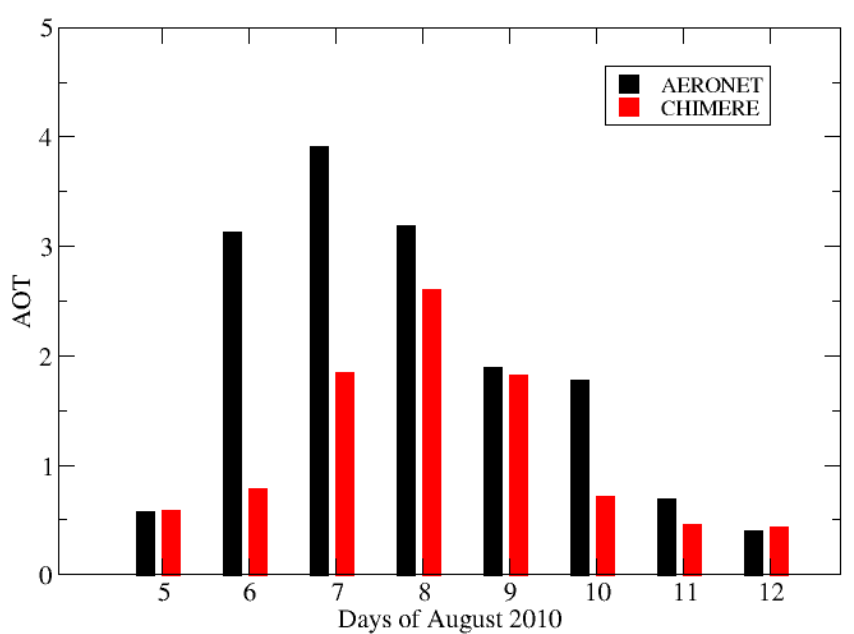

Figure 2. Temporal evolution of the daily mean AOT over Moscow modeled by CHIMERE (at $400 \mathrm{~nm}$ ) and measured by AERONET (at $440 \mathrm{~nm}$ ) between 5 and 12 August 2010.

Photolysis is the process breaking the covalent bond of some reactive gaseous species by short-wave solar radiation. This process is very important in the atmosphere as it controls the abundance of numerous air pollutants such as ozone and nitrogen dioxide. The photolysis rate of a given species $J\left(\mathrm{~s}^{-1}\right)$ is calculated as follows:

$J\left(\mathrm{~s}^{-1}\right)=\int_{\lambda_{1}}^{\lambda_{2}} \sigma(\lambda, T) \cdot \phi(\lambda, T) \cdot F(\lambda) d \lambda$,

where $\sigma(\lambda, T)$ and $\phi(\lambda, T)$ are, respectively, the absorption cross section $\left(\mathrm{cm}^{2}\right)$ and the quantum yield of a given molecule, $T$ the air temperature $(\mathrm{K})$ and $F(\lambda)$ the actinic flux between wavelengths $\lambda_{1}$ and $\lambda_{2}$ (photons $\mathrm{cm}^{-2} \mathrm{~s}^{-1} \mathrm{~nm}^{-1}$ ). The absorption cross section reflects the probability of collision between a photon and the molecule, while the quantum yield is the probability that the molecule is dissociated after collision with a photon. The dependence of both parameters on the air temperature is calculated by TUV by using the vertical profile of air temperature issued from the meteorological model WRF used to drive CHIMERE.

The actinic flux is calculated by integrating the solar flux over all sphere angles considering 5646 wavelengths between 120 and $1250 \mathrm{~nm}$. When going through the atmosphere, the actinic flux can be attenuated by molecular absorption and diffusion but also by the presence of clouds and aerosols. For clouds and aerosols, the attenuation is calculated by using their respective aerosol optical thickness, single scattering albedo and asymmetry parameter. In TUV, clouds are assumed to be horizontally homogeneous layers and are considered to be of three types: low-, middle- and high-altitude clouds. Altitudes of their bases and tops as well as their optical thicknesses are estimated by the meteorological model WRF. The single-scattering albedo and asymmetry 

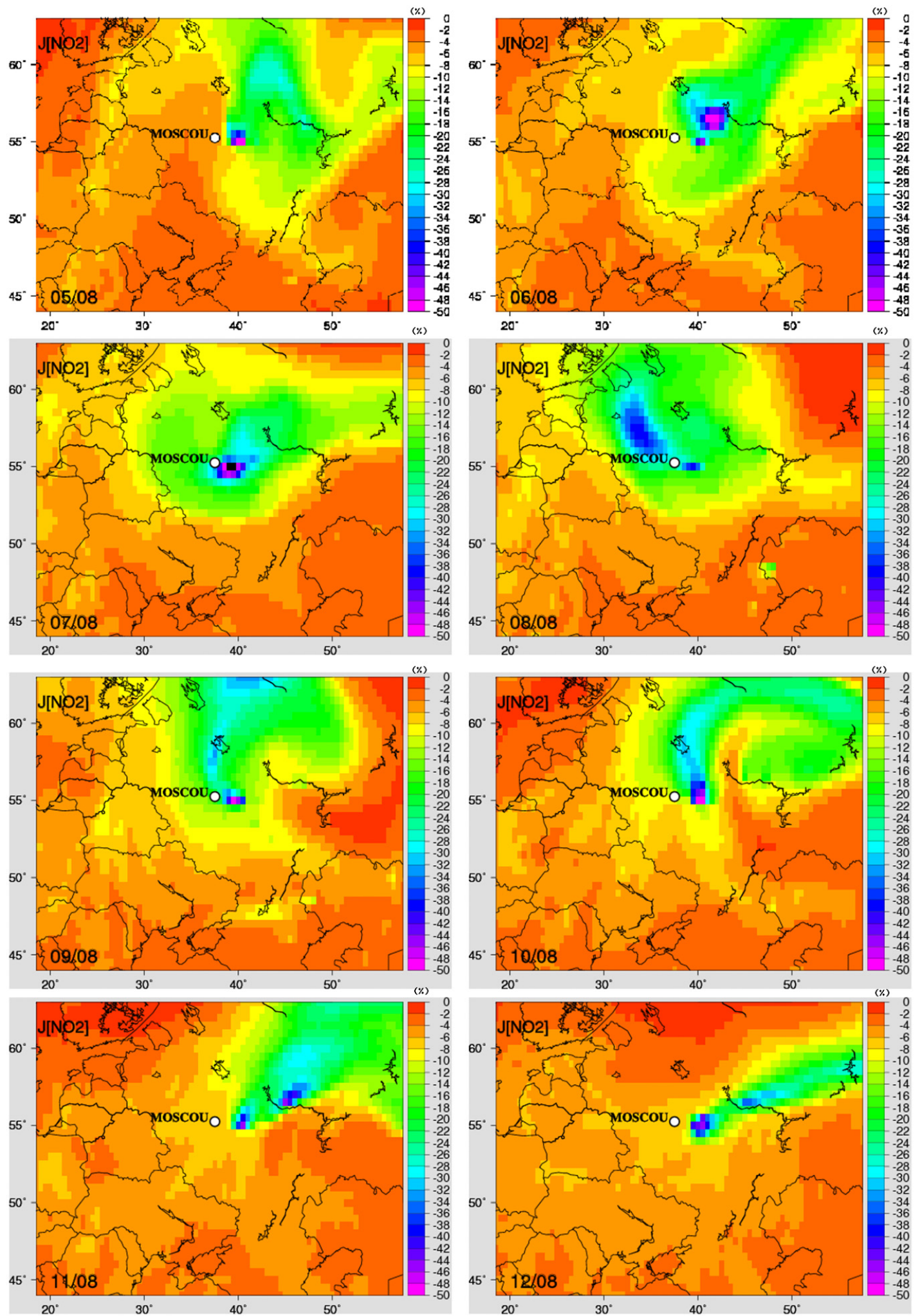

Figure 3. Geographic distribution of the modeled daytime average percentage changes in the near-surface $J\left[\mathrm{NO}_{2}\right]$ due to the presence of aerosols. 

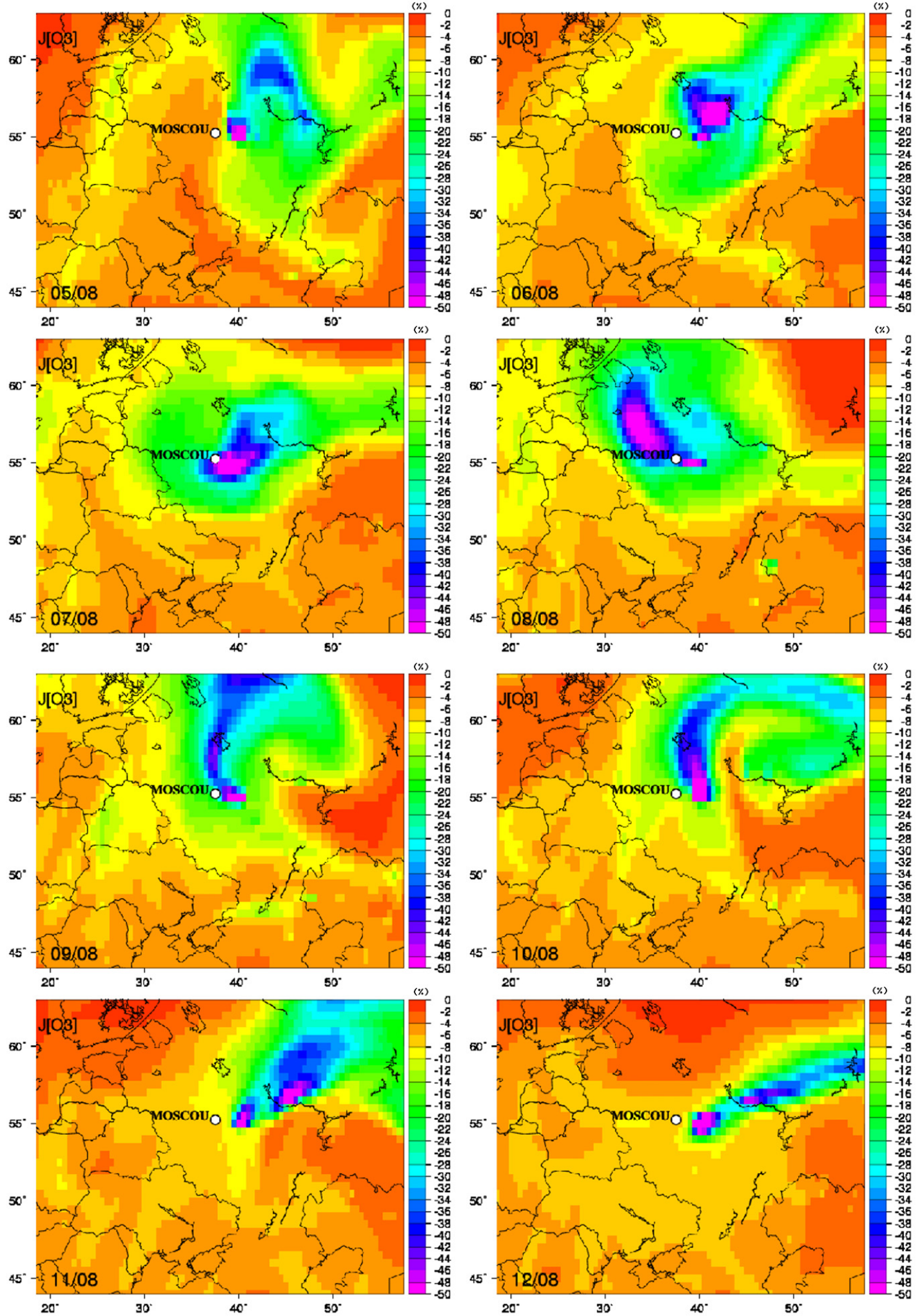

Figure 4. Geographic distribution of the modeled daytime average percentage changes in the near-surface $J\left[\mathrm{O}_{3}\right]$ due to the presence of aerosols. 
parameter are considered constant in the UV-visible wavelengths and are taken equal to, respectively, 0.99 and 0.85 for the three types of clouds (Madronich and Flocke, 1998). It should be noted that changes in the cloud optical properties due to the activation of aerosols into cloud condensation nuclei are not taken into account in our approach. However, the anticyclonic conditions that prevailed over eastern Europe during the studied period suggest a low impact of clouds on the modeled actinic flux and photolysis rates (Lau and Kim, 2012).

Concerning aerosols, the three optical properties (AOT, SSA and $g$ ) are calculated at 200, 300, 400, 500, 600 and $700 \mathrm{~nm}$ using the aerosol optical module and then interpolated to the TUV wavelength grid $(120-1250 \mathrm{~nm})$. To solve the radiative transfer equation and compute the actinic flux along the atmospheric column, the Eddington approximation has been chosen in TUV as it allows an accurate estimation of modeled radiative fluxes (Joseph et al., 1976).

Recently, Palancar et al. (2013) realized an intercomparison exercise between the TUV model and UV actinic flux measurements over Mexico during the MILAGRO campaign. They highlighted the good performance of the model in reproducing observations both at the surface and in the lower troposphere over this highly polluted area. This validation study gives us confidence in our estimation of photolysis rate perturbations by aerosols during the 2010 Russian wildfires presented hereinafter.

\subsection{Simulation set-up}

The methodology developed in this study consists of a oneway and online coupling between TUV and CHIMERE. In this approach, the radiative transfer code TUV has been implemented within CHIMERE so that each model runs simultaneously. During the simulation, the aerosol optical properties modeled by CHIMERE for a core-shell mixing (AOT, SSA, $g$ ) are used as inputs in TUV in order to take into account the influence of aerosol solar extinction on photolysis rates. Then, the photolysis rates estimated by TUV are in turn used by CHIMERE to calculate the concentrations of photochemical pollutants.

Two simulations are performed for the period of peak fire activity (5-12 August 2010):

1. In the first one, the attenuation of actinic flux is only due to gases and clouds: CHIMERE-TUV(gases+clouds).

2. In the second one, the impact of aerosols on solar extinction is added in the photolysis rate calculation: CHIMERE-TUV(gases+clouds+aerosols).

The impact of aerosols on photolysis rates and associated concentrations of photochemical pollutants are then estimated by differencing the two simulations: $2-1$. It should be noted that adding the aerosol impact on solar extinction in simulation 2 induces a computation time increase of $50 \%$ compared to the simulation 1 .
We focus on the aerosol impact on $\mathrm{NO}_{2}$ and $\mathrm{O}_{3}$ photolysis rates, which mainly drives the concentration of ozone, $\mathrm{NO}_{2}$ and $\mathrm{OH}$ radicals in the troposphere. Indeed, the major source of ozone is the result of the $\mathrm{NO}_{2}$ photolysis:

$\mathrm{NO}_{2}+\hbar \cdot \vartheta \longrightarrow \mathrm{NO}+\mathrm{O}\left({ }^{3} \mathrm{P}\right) \quad J\left[\mathrm{NO}_{2}\right]$

followed by the reaction of $\mathrm{O}\left({ }^{3} \mathrm{P}\right)$ with a dioxygen molecule ( $M$ is a third body favoring the reaction):

$\mathrm{O}\left({ }^{3} \mathrm{P}\right)+\mathrm{O}_{2}+M \longrightarrow \mathrm{O}_{3}+M$.

Given that Reaction (3) is rapid, the formation rate of ozone is mainly determined by the constant rate $J\left[\mathrm{NO}_{2}\right]$. In parallel, the major sink of ozone during daytime is its photodissociation following the reaction

$\mathrm{O}_{3}+\hbar \cdot \vartheta \longrightarrow \mathrm{O}_{2}+\mathrm{O}\left({ }^{1} \mathrm{D}\right) \quad J\left[\mathrm{O}_{3}\right]$.

$\mathrm{O}\left({ }^{1} \mathrm{D}\right)$ will rapidly react with a water molecule to form $\mathrm{OH}$ radicals:

$\mathrm{O}\left({ }^{1} \mathrm{D}\right)+\mathrm{H}_{2} \mathrm{O} \longrightarrow 2 \mathrm{OH}$.

The latter reaction is a major source of $\mathrm{OH}$ radicals in the troposphere. They are involved in the formation of secondary particles as oxidants of their gaseous precursors. For example, they contribute to the oxidation of $\mathrm{SO}_{2}, \mathrm{NO}_{2}$ and $\mathrm{VOC}$, which can result in the formation of, respectively, sulfate, nitrate and secondary organic aerosols. The sequence of Reactions (R1) to (R4) is generally initiated by the reaction of various $\mathrm{VOC}$ with the $\mathrm{OH}$ radical.

\section{Results and discussion}

\subsection{Regional impact of the 2010 Russian wildfires on the formation of ozone and nitrogen dioxide}

During the wildfire episode, the important concentrations of scattering aerosols have affected significantly the UV-visible solar radiation in terms of intensity and spatial extent. Figures 3 and 4 report the daytime average percentage changes in near-surface photolysis rates of $\mathrm{NO}_{2}$ and $\mathrm{O}_{3}$, respectively. Changes are shown to be negative over the entire area with mean daytime values between -2 and $-50 \%$ and closely follow the AOT spatial features (see Fig. 1). It is interesting to note that the impact of the aerosol solar extinction is more pronounced for $J\left[\mathrm{O}_{3}\right]$ than for $J\left[\mathrm{NO}_{2}\right]$, for each day of the studied period. For both photolysis rates, the largest reduction is simulated along the transport of the aerosol plume (20-50\%). The photochemistry over the Moscow region has also been affected, especially during the arrival of the aerosol plume between 6 and 10 August 2010. This point will be discussed in further detail in what follows. The modeled changes obtained here are comparable with the recent study of Real and Sartelet (2011) in which they simulate, by using the chemistry-transport model PolyphemusPolair3D coupled with the radiative transfer code Fast-J, a 
reduction of $J\left[\mathrm{NO}_{2}\right]$ and $J\left[\mathrm{O}_{3}\right]$ reaching $30 \%$ (in monthly mean) during summer 2001 over European regions characterized by elevated AOT $(0.6-0.7$ at $550 \mathrm{~nm})$. Also, Hodzic et al. (2007) simulated a $15-30 \% \mathrm{NO}_{2}$ photolysis reduction during the 2003 European summer heatwave in the case of absorbing biomass burning aerosols (AOT $(550 \mathrm{~nm})=0.7-$ 0.8 , SSA $(532 \mathrm{~nm})=0.83-0.87)$.

According to Reactions (R1) to (R4), the alteration of $J\left[\mathrm{NO}_{2}\right]$ and $J\left[\mathrm{O}_{3}\right]$ in the presence of aerosols suggests, in turn, a modification of their concentrations near the surface. Figure 5 gives an example of these corresponding changes during the 8 August for $\mathrm{NO}_{2}$ and $\mathrm{O}_{3}$. Some notable modification of the $\mathrm{NO}_{2}$ concentration is simulated, as it is mainly driven during daytime by its photolytic destruction (see Reaction R1). The important diminution of $J\left[\mathrm{NO}_{2}\right]$ due to aerosols (between 2 and $50 \%$ ) leads to an increase of its near-surface concentration reaching, on average, 3 to $15 \%$. Concerning ozone, its daytime concentration is influenced by both variations of $J\left[\mathrm{NO}_{2}\right]$ (source of ozone, see Reactions R1 and R2) and variations of $J\left[\mathrm{O}_{3}\right]$ (sink of ozone, see Reaction R3). We can deduce from Fig. 5 that the influence of $J\left[\mathrm{NO}_{2}\right]$ reduction seems to slightly dominate the influence of $J\left[\mathrm{O}_{3}\right]$ reduction, resulting in a decrease of the near-surface concentration of ozone between 1 and $12 \%$. These results are comparable to those obtained by Real and Sartelet (2011) who simulated a 4-8\% reduction of nearsurface ozone concentration (for July 2001) over areas where the decrease of $J\left[\mathrm{NO}_{2}\right]$, due to the aerosol solar extinction, reached $30 \%$. Also, Mena-Carrasco et al. (2009) highlighted, by combining STEM-2K3 model experiments and aircraft observations from the MILAGRO campaign during March 2006, a $40 \%$ attenuation of $J\left[\mathrm{NO}_{2}\right]$ associated with an intense aerosol plume over Mexico City, resulting in a 5-10\% diminution of ozone production. Such impacts are however less pronounced than the ones obtained over some highly polluted Asian regions. For example, Bian et al. (2007) and Wai and Tanner (2010) showed, over China, a reduction of maximum ozone concentration reaching 30 to $70 \%$ associated with similar aerosol loadings as obtained in our study $(1<\operatorname{AOT}(550 \mathrm{~nm})<2.5)$. The low absorbing properties of the Russian smoke plume (Péré et al., 2014) could be a reason for such a behavior.

To further investigate aerosol feedback on the ozone cycle and the formation of secondary particles, we will now focus our study on the Moscow region where the aerosol solar extinction is pronounced, especially during the aerosol plume overpass (6-10 August 2010). Gaseous and particulate measurements from the Moscow air quality station will also be used in the analysis.

\subsection{Impact of the 2010 Russian wildfires on the photochemistry over Moscow}

In Fig. 6, the impact of particles on the formation of ozone and nitrogen dioxide over Moscow is shown in terms of day- time average percentage changes in their near-surface photolysis frequencies and concentrations as a function of modeled AOT $(440 \mathrm{~nm})$. As expected, changes appear to have a good linearity with AOT $(440 \mathrm{~nm})$ with a correlation of $0.90-0.95$ - i.e, modifications become more important when the aerosol loading increases. As shown previously over the entire area, $J\left[\mathrm{O}_{3}\right]$ is more sensitive to the presence of particles (reduction of about $10 \%$ per unit of AOT) than $J\left[\mathrm{NO}_{2}\right]$ (reduction of about $6 \%$ per unit of AOT). These modifications of photolysis rates result in an increase of the ground $\mathrm{NO}_{2}$ concentration of $3 \%$ (per unit of AOT). The response of the ozone concentration under the aerosol radiative influence is more complex. Indeed, ozone formation is driven by two major precursors: nitrogen oxides $\left(\mathrm{NO}_{x}=\mathrm{NO}\right.$ $+\mathrm{NO}_{2}$ ) and volatile organic compounds (VOC) in a complex photochemistry. However, it is possible to identify two regimes of ozone formation by looking at the ratio between the concentrations of VOC and $\mathrm{NO}_{x}:$ a $\mathrm{NO}_{x}$-limited and a $\mathrm{NO}_{x}$-saturated regime (Seinfeld and Pandis, 1998). Based on the study of Dodge (1977) on ozone chemical mechanisms, a VOC(ppmC) $/ \mathrm{NO}_{x}(\mathrm{ppm})$ ratio below 4 defines a $\mathrm{NO}_{x}$ saturated environment. Figure 7 indicates that such photochemical regime occurred over Moscow during the studied period, with a $\mathrm{VOC}(\mathrm{ppmC}) / \mathrm{NO}_{x}(\mathrm{ppm})$ ratio always below this threshold. In this case, inclusion of the aerosol radiative impact on photochemistry leads to two antagonistic responses: (1) increase of $\mathrm{NO}_{x}$ concentration trough reduction of photolysis rates is unfavorable to ozone formation in a $\mathrm{NO}_{x}$-saturated environment, and in parallel, (2) reduction of the ozone photolysis is favorable to its accumulation. The overall impact of aerosols on the ozone concentration is then small due to these two antagonistic responses - about $1 \%$ per unit of AOT (see Fig. 6). The influence of aerosols on photochemistry does not only occur at the surface but also in the low troposphere, as illustrated in Fig. 8. This figure presents the aerosol extinction coefficient (in $\mathrm{km}^{-1}$ ) modeled by CHIMERE and retrieved by CALIOP for the $9 \mathrm{Au}-$ gust inside and outside the intense aerosol plume (see Fig. 1 for the localizations of these two points). The vertical profile of the daytime average percentage changes in the ozone concentration due to this intense aerosol plume is also indicated. We can see that inside the intense fire plume, more than $70 \%$ of the aerosol extinction is measured below the first two kilometers of the atmosphere with values reaching $0.5-0.95 \mathrm{~km}^{-1}$, indicating a low-altitude transport. Above, CALIOP aerosol extinction gradually decreases to become negligible at an altitude of $5 \mathrm{~km}$. For comparison, outside the intense fire plume, particles remain confined near the ground, with a much lower aerosol extinction (maximum value of $0.15 \mathrm{~km}^{-1}$ at an altitude of $200 \mathrm{~m}$ ), suggesting a prevailing anthropogenic origin. CHIMERE compares well with CALIOP extinction coefficients within the uncertainty range of measurements for both cases, giving confidence in the estimated impact of aerosols on the ozone reduction. This ozone reduction, due to the presence of the intense aerosol plume, 

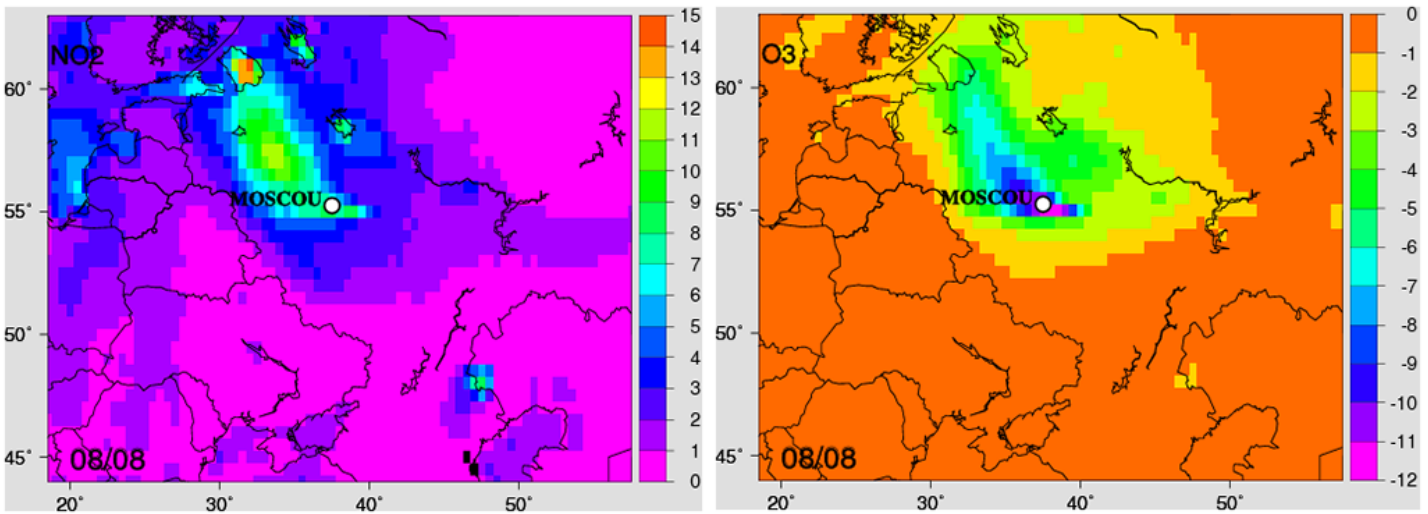

Figure 5. Geographic distribution of the daytime average percentage changes in the near-surface concentration of $\mathrm{NO}_{2}$ (left) and $\mathrm{O}_{3}$ (right) for the 8 August 2010, due to the presence of aerosols.
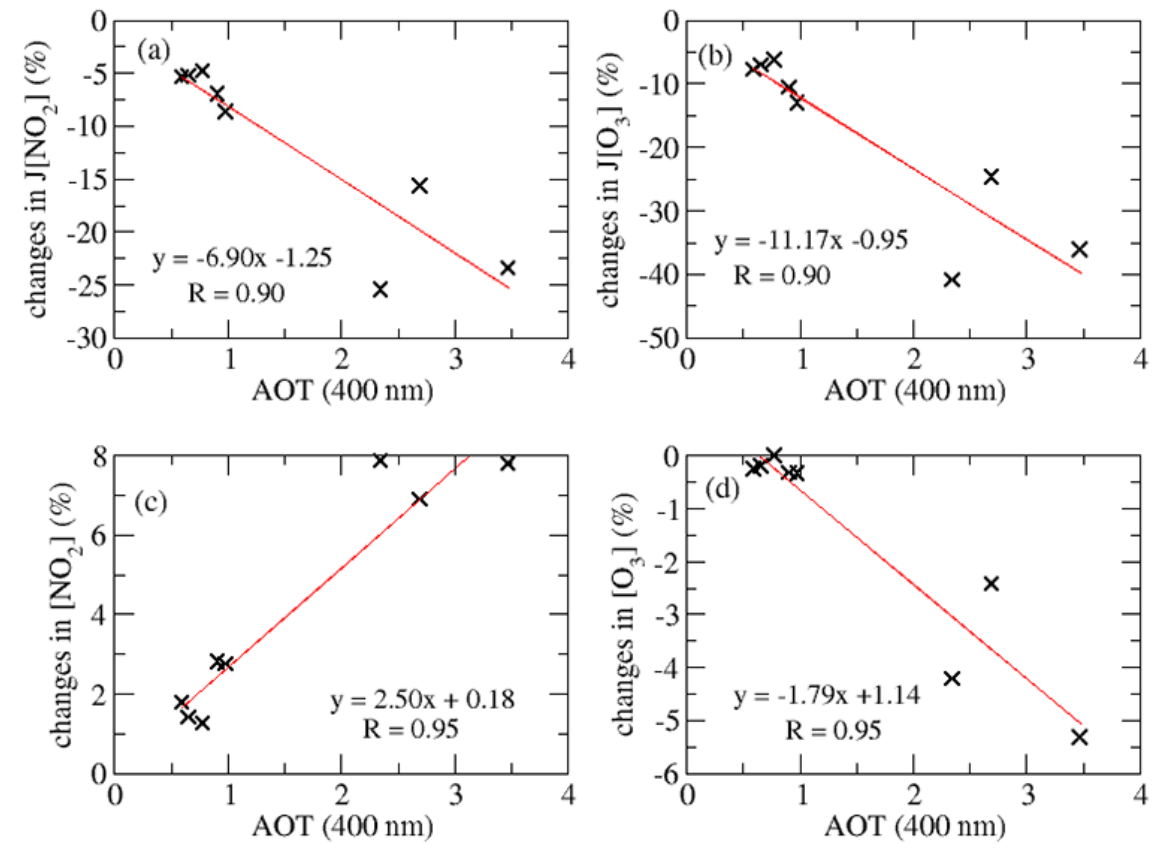

Figure 6. Daytime average percentage changes in the photolysis frequencies and concentrations of nitrogen dioxide and ozone over Moscow as a function of modeled AOT $(440 \mathrm{~nm})$.

is maximum (4-5\%) below an altitude of $2 \mathrm{~km}$ where most of the aerosol extinction occurs and then gradually decreases with the altitude.

In terms of model performance, it is interesting to see whether an explicit representation of aerosol impact on photolysis rates tends to improve the simulation of the concentration of photochemical pollutants, compared to a simulation without aerosol feedback. For such analyses, statistical comparisons between the near-surface concentrations of $\mathrm{NO}_{2}$ and $\mathrm{O}_{3}$ simulated with and without aerosols and measured at Moscow by an air quality station have been made. The results are presented in Tables 1 and 2 for hourly values and daily maximum values, respectively. We can see that, for both con- figurations, scores for ozone and $\mathrm{NO}_{2}$ are of $48-88 \mu \mathrm{g} \mathrm{m}^{-3}$ for the RMSE and of 0.22-0.60 for the temporal correlation. Such biases could be the consequence of possible uncertainties in the EMEP anthropogenic emission inventory used in the present study. Indeed, it should be noted that Bessagnet et al. (2014), who performed an extensive intercomparison study between several European state-of-the-art chemistrytransport models (including CHIMERE) and EMEP measurements, also showed a model $\mathrm{NO}_{2}$ and ozone underestimation over Europe in the frame of the EURODELTA III project. The model biases on these two species can induce a bias on the modeled photolysis rates as gaseous pollutants (especially $\mathrm{NO}_{2}$ ) may also influence actinic flux through di- 
Table 1. Statistical comparisons between the near-surface concentrations of $\mathrm{NO}_{2}$ and $\mathrm{O}_{3}$ simulated with and without aerosols and measured at Moscow by an air quality station. Mod. and Obs. are the period-averaged modeled and observed concentration. Corr. and RMSE are the temporal correlation and the root mean square error.

\begin{tabular}{|c|c|c|c|c|c|c|c|c|}
\hline & \multicolumn{4}{|c|}{$\mathrm{NO}_{2}$} & \multicolumn{4}{|c|}{$\mathrm{O}_{3}$} \\
\hline & $\begin{array}{c}\text { Mod. } \\
\left(\mu \mathrm{g} \mathrm{m}^{-3}\right)\end{array}$ & $\begin{array}{c}\text { Obs. } \\
\left(\mu \mathrm{g} \mathrm{m}^{-3}\right)\end{array}$ & Corr. & $\begin{array}{c}\text { RMSE } \\
\left(\mu \mathrm{g} \mathrm{m}^{-3}\right)\end{array}$ & $\begin{array}{c}\text { Mod. } \\
\left(\mu \mathrm{g} \mathrm{m}^{-3}\right)\end{array}$ & $\begin{array}{c}\text { Obs. } \\
\left(\mu \mathrm{g} \mathrm{m}^{-3}\right)\end{array}$ & Corr. & $\begin{array}{c}\text { RMSE } \\
\left(\mu \mathrm{g} \mathrm{m}^{-3}\right)\end{array}$ \\
\hline With & 14 & 70 & 0.22 & 66 & 129 & 66 & 0.46 & 82 \\
\hline Without & 13 & 70 & 0.21 & 67 & 134 & 66 & 0.42 & 88 \\
\hline
\end{tabular}

Table 2. As Table 1, but for daily maximum values.

\begin{tabular}{lccccccccc}
\hline & \multicolumn{4}{c}{$\mathrm{NO}_{2}$} & & \multicolumn{3}{c}{$\mathrm{O}_{3}$} \\
\cline { 2 - 4 } \cline { 8 - 10 } & $\begin{array}{c}\text { Mod. } \\
\left(\mu \mathrm{g} \mathrm{m}^{-3}\right)\end{array}$ & $\begin{array}{c}\text { Obs. } \\
\left(\mu \mathrm{g} \mathrm{m}^{-3}\right)\end{array}$ & Corr. & $\begin{array}{c}\text { RMSE } \\
\left(\mu \mathrm{g} \mathrm{m}^{-3}\right)\end{array}$ & & $\begin{array}{c}\text { Mod. } \\
\left(\mu \mathrm{g} \mathrm{m}^{-3}\right)\end{array}$ & $\begin{array}{c}\text { Obs. } \\
\left(\mu \mathrm{g} \mathrm{m}^{-3}\right)\end{array}$ & Corr. & $\begin{array}{c}\text { RMSE } \\
\left(\mu \mathrm{g} \mathrm{m}^{-3}\right)\end{array}$ \\
\hline With & 32 & 90 & 0.60 & 66 & & 180 & 161 & 0.19 & 48 \\
Without & 31 & 90 & 0.60 & 67 & & 185 & 161 & 0.16 & 54 \\
\hline
\end{tabular}

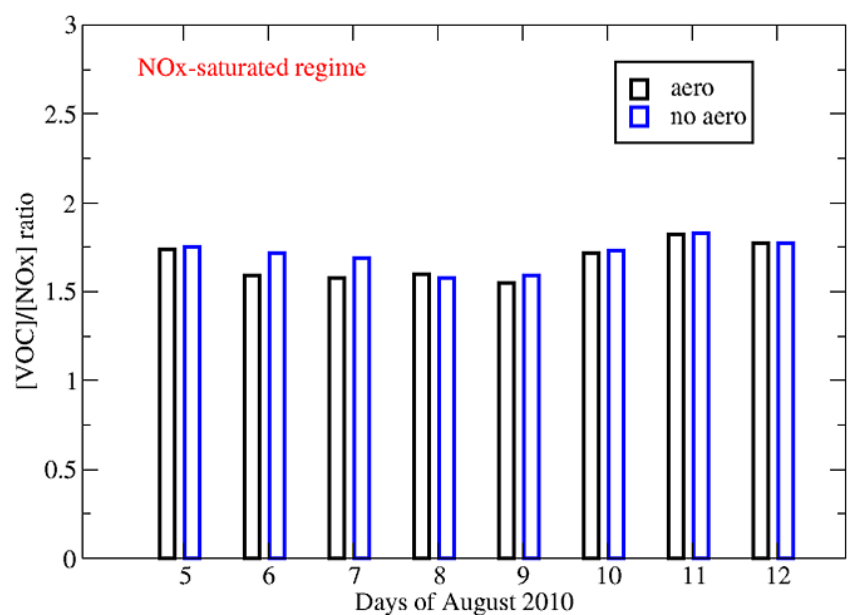

Figure 7. Mean VOC (ppmC) to $\mathrm{NO}_{x}$ (ppm) ratio simulated over Moscow during the studied period.

rect absorption. Unfortunately, quantifying this bias would require comparing simulated values of actinic flux with observations, which is not possible for this study as no such measurements are available to us for this specific event. However, a recent study by Palancar et al. (2013) estimated the relative influence of aerosols and $\mathrm{NO}_{2}$ on the actinic fluxes by comparing measurements made during the MILAGRO campaign over Mexico City with TUV model calculations. Comparisons indicate that aerosols and $\mathrm{NO}_{2}$ account for, respectively, 70 and $25 \%$ of actinic fluxes reduction observed at the surface. Hence, such results suggest a moderate impact of the $\mathrm{O}_{3}$ and $\mathrm{NO}_{2}$ CHIMERE biases on the photolysis rates simulated over Moscow during the 2010 wildfires episode. Overall, Tables 1 and 2 indicates that the inclusion of aerosols in the simulation improves the correlation and slightly reduces biases with measurements for both species and for both hourly and maximum values.

To further investigate the aerosol feedback on the ozone daytime cycle, Fig. 9 displays the temporal evolution (between 5 and 12 August 2010) of the near-surface ozone concentration (in $\mu \mathrm{g} \mathrm{m}^{-3}$ ) modeled with and without aerosol feedback along with corresponding observations at the Moscow monitoring station. This figure confirms the moderate overall impact of the aerosol solar extinction on the ozone production, with a maximum diminution reaching 7 $10 \%$ during the aerosol plume overpass (7, 8 and 9 August), which leads to a slightly reduced bias between model and observations. Depending on the day, the model simulates lower or higher hourly values compared to observations. The ozone model biases presented in Fig. 9 clearly show that some processes are missing and/or not well represented in the CHIMERE model. Among these processes, adding the aerosol direct radiative impact on the simulation of photolysis rates could improve the estimation of ozone formation for some days. However, it is obvious that this process does not entirely explain model biases. As indicated previously, uncertainties on the EMEP emission database for this specific region could be a possible reason for these biases. Also, the model is shown to overestimate nighttime concentrations over the period, which could be due to uncertainties in correctly estimating its dry deposition and titration by $\mathrm{NO}$, as previously highlighted by Honoré et al. (2008) over western Europe. It should be noted that an inadequate representation of the nocturnal air ventilation could also be a reason for such a model bias.

In parallel, the presence of aerosols tends to reduce the oxidizing capacity of the atmosphere (through reduction of $\mathrm{OH}$ radicals, see Reaction $\mathrm{R} 4$ ), which leads to a decrease in the 


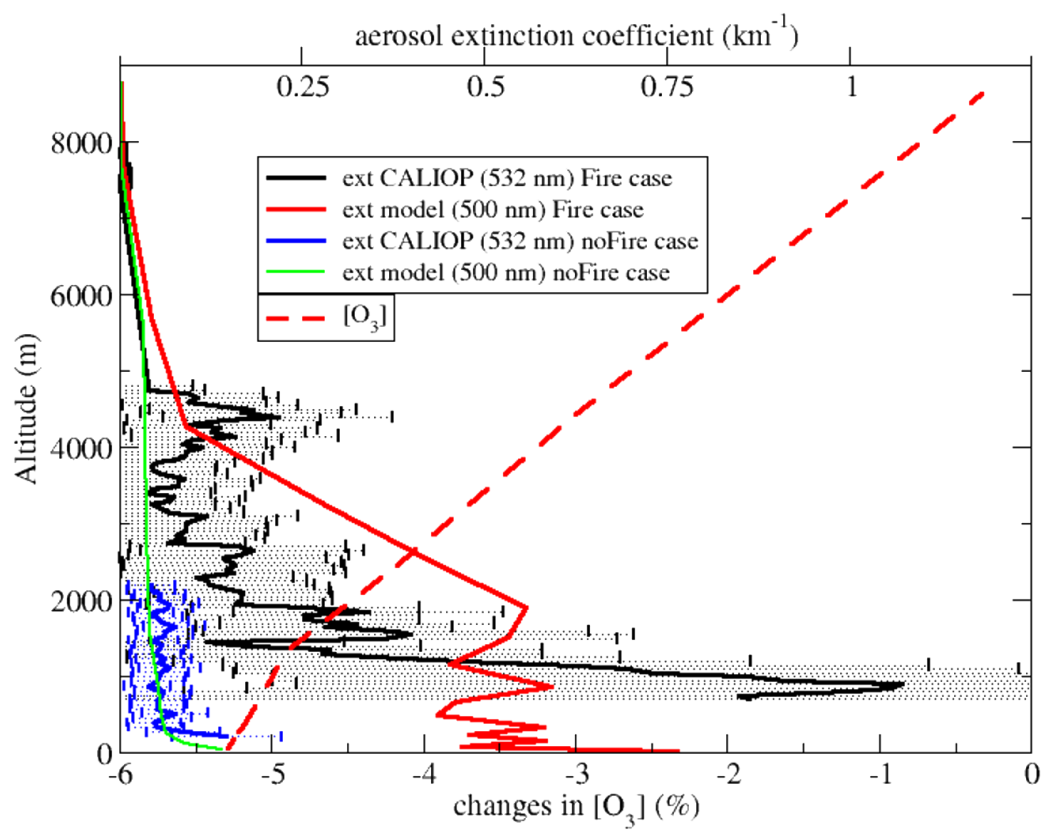

Figure 8. The aerosol extinction coefficient (in $\mathrm{km}^{-1}$ ) modeled by CHIMERE and measured by CALIOP for the 9 August inside (Fire case, $37.6^{\circ} \mathrm{E}, 59.9^{\circ} \mathrm{N}$ ) and outside (noFire case, $33.3^{\circ} \mathrm{E}, 52.0^{\circ} \mathrm{N}$ ) the intense aerosol plume (dotted lines correspond to the uncertainties on CALIOP measurements). The localization of these two points is indicated on Fig. 1. The vertical profile of the daytime average percentage changes in the ozone concentration due to this intense aerosol plume is indicated by the red dashed line.

Table 3. As Table, 1 but for the near-surface concentrations of ammonium, nitrates and sulfates. Measurements come from the Danki EMEP station RU0018R (near Moscow) located at $54.9^{\circ} \mathrm{N}$ and $37.8^{\circ} \mathrm{E}$.

\begin{tabular}{|c|c|c|c|c|c|c|c|c|c|c|c|c|}
\hline & \multicolumn{4}{|c|}{$\mathrm{NH}_{4}^{+}$} & \multicolumn{4}{|c|}{$\mathrm{NO}_{3}^{-}$} & \multicolumn{4}{|c|}{$\mathrm{SO}_{4}^{2-}$} \\
\hline & $\begin{array}{c}\text { Mod. } \\
\left(\mu \mathrm{g} \mathrm{m}^{-3}\right)\end{array}$ & $\begin{array}{c}\text { Obs. } \\
\left(\mu \mathrm{g} \mathrm{m}^{-3}\right)\end{array}$ & Corr. & $\begin{array}{c}\text { RMSE } \\
\left(\mu \mathrm{g} \mathrm{m}^{-3}\right)\end{array}$ & $\begin{array}{c}\text { Mod. } \\
\left(\mu \mathrm{g} \mathrm{m}^{-3}\right)\end{array}$ & $\begin{array}{c}\text { Obs. } \\
\left(\mu \mathrm{g} \mathrm{m}^{-3}\right)\end{array}$ & Corr. & $\begin{array}{c}\text { RMSE } \\
\left(\mu \mathrm{g} \mathrm{m}^{-3}\right)\end{array}$ & $\begin{array}{c}\text { Mod. } \\
\left(\mu \mathrm{g} \mathrm{m}^{-3}\right)\end{array}$ & $\begin{array}{c}\text { Obs. } \\
\left(\mu \mathrm{g} \mathrm{m}^{-3}\right)\end{array}$ & Corr. & $\begin{array}{c}\text { RMSE } \\
\left(\mu \mathrm{g} \mathrm{m}^{-3}\right)\end{array}$ \\
\hline With & 1.09 & 0.86 & 0.48 & 1.03 & 0.14 & 0.12 & 0.20 & 0.15 & 2.24 & 0.48 & 0.23 & 1.80 \\
\hline Without & 1.16 & 0.86 & 0.42 & 1.04 & 0.19 & 0.12 & 0.26 & 0.23 & 2.33 & 0.48 & 0.45 & 1.88 \\
\hline
\end{tabular}

formation of secondary aerosols. As illustrated in Fig. 10a, the maximum reduction in the near-surface concentrations of sulfates (oxidation product of $\mathrm{SO}_{2}$ ) and $\mathrm{SOA}$ (oxidation product of VOC) occurs on 8 August with daytime average values of 10 and $4 \%$, respectively. For this day, Fig. 10b shows that these changes are mainly due to a reduced formation of very fine particles - i.e, with a diameter between $40 \mathrm{~nm}$ (bin 1) and $300 \mathrm{~nm}$ (bin 4). The overall impact is then a slight reduction of the total aerosol mass concentration $\left(\mathrm{PM}_{10}\right)$ of between 1 and $2 \%$ over the entire period (Fig. 10a). These results are comparable to the findings of Real and Sartelet (2011) and G. Li et al. (2011) who showed a 5-10\% reduction of the formation of secondary aerosols due to the aerosol solar extinction, in the case of intense particulate pollution over, respectively, Europe and Mexico City. As for $\mathrm{NO}_{2}$ and $\mathrm{O}_{3}$, including the optical effect of aerosols in the photolysis calculations slightly improves the formation of secondary inorganic species in the CHIMERE model with a RMSE systematically reduced (see Table 3 ). The large over- estimation of sulfate concentrations is slightly decreased and the simulated concentrations of ammonium and nitrates get closer to the observed one. However, the correlations are not always improved when taking into account the aerosol radiative influence. The large overestimation of scattering sulfate particles is expected to have a low influence on the estimation of aerosol impact on photolysis rates as this chemical species represents less than $10 \%$ of the total chemical composition modeled over Moscow during the study period (Péré et al., 2014). This is confirmed by the excellent agreement between modeled and measured SSA during this specific event (as discussed in Sect. 2.1.2), which is a key factor in the determination of a particle's interaction with the actinic flux. Even if some discrepancies between measurements and model simulation results are present, Table 3 suggests that taking into account the aerosol solar extinction in the photolysis calculation can improve the model capacity to reproduce the photochemistry under polluted environments. 


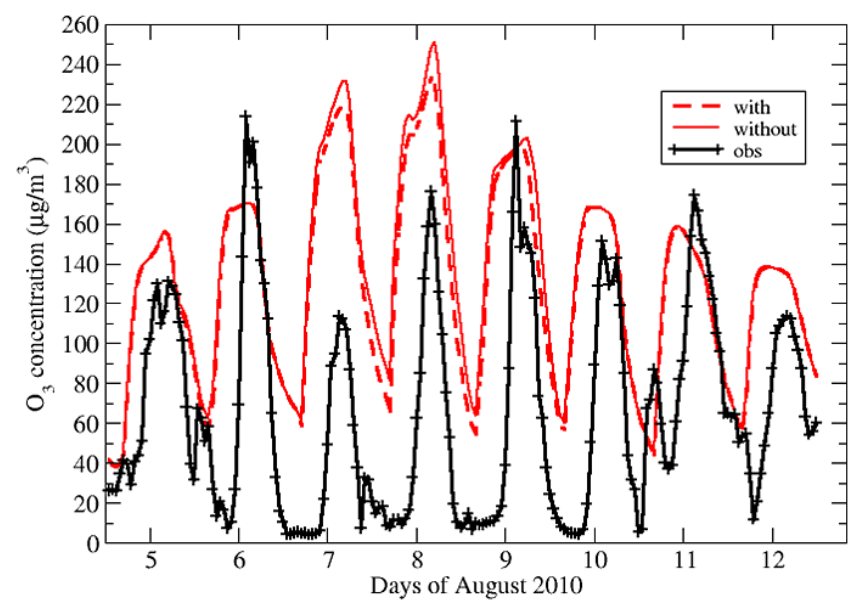

Figure 9. Temporal evolution (between 5 and 12 August 2010) of the near-surface ozone concentration (in $\mu \mathrm{g} \mathrm{m}^{-3}$ ) modeled with and without aerosol feedback along with corresponding observations at the Moscow monitoring station.

\section{Conclusions}

In the present study, we have developed an online coupling between the chemistry-transport model CHIMERE (complemented by an aerosol optical module) and the radiative transfer code TUV to study the impact of aerosol solar extinction on the photochemistry over eastern Europe during the 2010 wildfires episode. Simulations from 5 to $12 \mathrm{Au}$ gust 2010, corresponding to the peak of fire activity, have been performed with and without aerosol impact on photolysis rates and concentrations of gaseous and particulate pollutants. MODIS observations highlight this important particulate pollution episode with AOT $(550 \mathrm{~nm})$ above 1 over large areas and values up to 4 along the intense fire plume transported in the anticyclonic flow. The model is able to reproduce the main aerosol plume features in terms of transport (spatial correlation of $0.4-0.8$ ) and intensity (normalized mean bias of $-(15-40 \%)$ ) during this specific period. The altitude of transport was shown to be below $5 \mathrm{~km}$ and comparisons between CHIMERE and CALIOP show good consistency. A large enhancement of the particulate pollution is detected over Moscow when the plume overpasses the area, with an AERONET AOT $(440 \mathrm{~nm})$ from 0.56 on 5 August to 2-4 between 6 and 10 August. CHIMERE simulates rather well the temporal evolution of the AOT over Moscow during this period with biases from -53 to $8 \%$, except for the 6 and 10 August. For these two days, the model underestimation is of $60-75 \%$ due to some model deficiencies in simulating the transport of the intense aerosol plume over Moscow. Organic species are the dominant part of the aerosol composition simulated by CHIMERE over this area due to large OC and VOC emissions (mainly from wildfires with also an anthropogenic contribution), which lead to high SSA modeled over Moscow throughout the period with val-
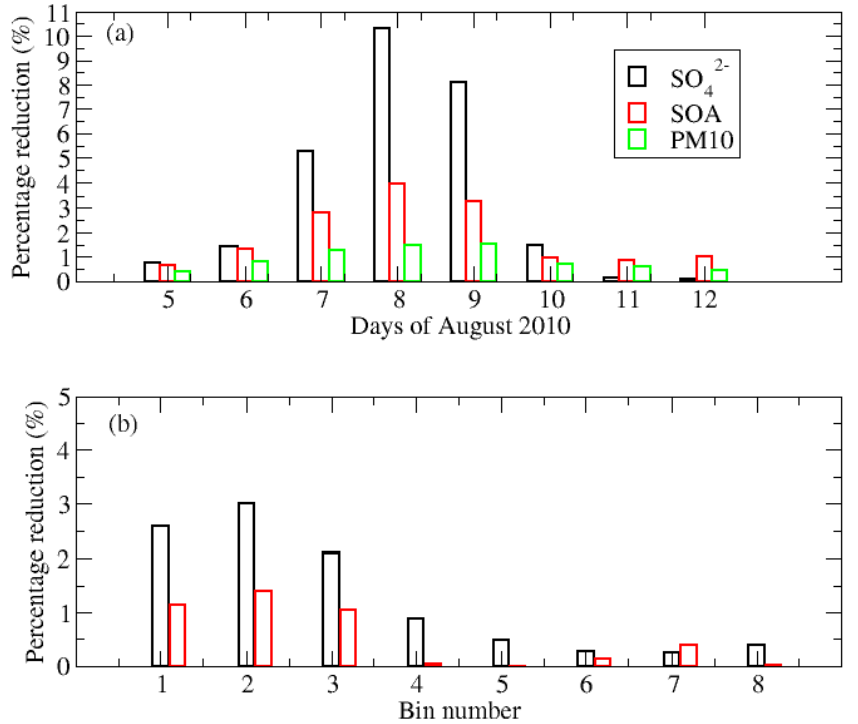

Figure 10. (a) Daytime average percentage reduction of the nearsurface concentration of sulfates, secondary organic aerosols and $\mathrm{PM}_{10}$ over Moscow due to the aerosol feedback. (b) Repartition of this sulfate and SOA mass reduction between the eight aerosol size bins for the 8 August.

ues of 0.97 (between 300 and $1000 \mathrm{~nm}$ ), in good agreement with AERONET measurements over Moscow (0.95-0.96 between 440 and $1020 \mathrm{~nm}$ ).

The impact of aerosols on photolysis rates is shown to be regionally significant with a mean reduction of $J\left[\mathrm{NO}_{2}\right]$ and $J\left[\mathrm{O}_{3}\right]$ comprised between 2 and $50 \%$, the maximum reduction being modeled in the aerosol plume. These modifications of photolysis frequencies result in a regional increase in the daytime concentration of $\mathrm{NO}_{2}$ of $3-15 \%$ and a decrease in the $\mathrm{O}_{3}$ production near the surface of between 1 and $12 \%$ on 8 August.

The photochemistry over the Moscow region has also been affected, especially during the arrival of the aerosol plume between 6 and 10 August 2010. Over this area, results indicate that $J\left[\mathrm{O}_{3}\right]$ is more sensitive to the presence of particles (reduction of about $10 \%$ per unit of AOT) than $J\left[\mathrm{NO}_{2}\right]$ (reduction of about $6 \%$ per unit of AOT), resulting in an increase of the ground $\mathrm{NO}_{2}$ concentration of $3 \%$ (per unit of AOT) and a small reduction of ozone of $1 \%$ (per unit of AOT). The photochemistry is shown to be impacted along the boundary layer where aerosols are located with, for example, a 4-5\% $\mathrm{O}_{3}$ reduction modeled during 9 August within the first two $\mathrm{km}$ of the atmosphere.

In addition, the impact of aerosols on photolysis rates is shown to have an influence on the formation of secondary aerosols, through the modification of the $\mathrm{OH}$ concentration. Over Moscow, the aerosol plume tends to decrease the daytime concentrations of sulfates and secondary organics up to $4-10 \%$, which result in a small reduction of the total particulate concentration $\left(\mathrm{PM}_{10}\right)$ of $1-2 \%$ on average over the 
period. The results presented in this work, obtained from a modeling exercise, are consistent with those obtained in recent studies by combining model experiments and different sets of observations. In terms of model performance, comparisons of simulations with air quality measurements at Moscow indicate that an explicit representation of aerosol interaction with photolysis rates tends to improve the estimation of the near-surface concentration of ozone and nitrogen dioxide as well as the formation of inorganic aerosol species such as ammonium, nitrates and sulfates.

Recently, it has been suggested that some organic aerosols can absorb solar radiation, especially at the shorter visible and UV wavelengths (Zhong and Jang, 2011; Saleh et al., 2014). The methodology developed in this study provides a powerful tool to investigate the role of enhanced UV absorption by secondary organics on photochemistry at regional and urban scales.

Acknowledgements. The authors are grateful to the CRI at Lille 1, François Thieuleux at LOA and Anthony Ung at INERIS for their technical support. Olga Kislova at Mosecomonitoring (Moscow) is acknowledged for providing the surface air quality measurements used in this study. The authors would also like to thank Isabelle Chiapello at LOA for fruitful scientific discussion. The French CNES is acknowledged for its financial support.

Edited by: J. West

\section{References}

Amin, N.: Effect of ozone on the relative yield of rice crop in Japan evaluated based on monitored concentrations, Water Air Soil Pollut., 225, 1-9, 2014.

Beelen, R., Raaschou-Nielsen, O., Stafoggia, M., Andersen, Z. J., Weinmayr, G., Hoffmann, B., Wolf, K., Samoli, E., Fischer, P., Nieuwenhuijsen, M., Vineis, P., Xun, W. W., Katsouyanni, K., Dimakopoulou, K., Oudin, A., Forsberg, B., Modig, L., Havulinna, A. S., Lanki, T., Turunen, A., Oftedal, B., Nystad, W., Nafstad, P., De Faire, U., Pedersen, N. L., Östenson, C. G., Fratiglioni, L., Penell, J., Korek, M., Pershagen, G., Eriksen, K. T., Overvad, K., Ellermann, T., Eeftens, M., Peeters, P. H., Meliefste, K., Wang, M., Bueno-de-Mesquita, B., Sugiri, D., Krämer, U., Heinrich, J., de Hoogh, K., Key, T., Peters, A., Hampel, R., Concin, H., Nagel, G., Ineichen, A., Schaffner, E., ProbstHensch, N., Künzli, N., Schindler, C., Schikowski, T., Adam, M., Phuleria, H., Vilier, A., Clavel-Chapelon, F., Declercq, C., Grioni, S., Krogh, V., Tsai, M. Y., Ricceri, F., Sacerdote, C., Galassi, C., Migliore, E., Ranzi, A., Cesaroni, G., Badaloni, C., Forastiere, F., Tamayo, I., Amiano, P., Dorronsoro, M., Katsoulis, M., Trichopoulou, A., Brunekreef, B., and Hoek, G.: Effects of long-term exposure to air pollution on natural-cause mortality: an analysis of 22 European cohorts within the multicentre ESCAPE project, The Lancet, 383, 785-795, 2014.

Bessagnet, B., Hodzic, A., Vautard, R., Beekmann, M., Cheinet, S., Honoré, C., Liousse, C., and Rouil, L.: Aerosol modeling with
CHIMERE - Preliminary evaluation at the continental scale, Atmos. Environ., 38, 2803-2817, 2004.

Bessagnet, B., Menut, L., Curci, G., Hodzic, A., Guillaume, B., Liousse, C., Moukhtar, S., Pun, B., Seigneur, C., and Schulz, M.: Regional modeling of carbonaceous aerosols over Europe-focus on secondary organic aerosols, J. Atmos. Chem., 61, 175-202, doi:10.1007/s10874-009-9129-2, 2008.

Bessagnet, B., Colette, A., Meleux, F., Rouil, L., Ung, A., Favez, O., Cuvelier, C., Thunis, P., Tsyro, S., Stern, R., Manders, A., Kranenburg, R., Aulinger, A., Bieser, J., Mircea, M., Briganti, G., Cappelletti, A., Calori, G., Finardi, S., Silibello, C., Ciarelli, G., Aksoyoglu, S., Prévot, A., Pay, M.-T., Baldasano, J. M., García Vivanco, M., Garrido, J. L., Palomino, I., Martín, F., Pirovano, G., Roberts, P., Gonzalez, L., White, L., Menut, L., Dupont, J.-C., Carnevale, C., and Pederzoli, A.: The EURODELTA III exerciseModel evaluation with observations issued from the 2009 EMEP intensive period and standard measurements in February/March 2009, Technical EMEP report, 2014.

Bian, H., Han, S., Tie, X., Sun, M., and Liu, A.: Evidence of impact of aerosols on surface ozone concentration in Tianjin, China, Atmos. Environ., 41, 4672-4681, 2007.

Chen, F. and Dudhia, J.: Coupling an advanced landsurface/hydrology model with the Penn State/NCAR MM5 modeling system. Part 1: Model description and implementation, Mon. Weather Rev., 129, 569-585, 2001.

Chubarova, N., Nezval', Ye., Sviridenkov, I., Smirnov, A., and Slutsker, I.: Smoke aerosol and its radiative effects during extreme fire event over Central Russia in summer 2010, Atmos. Meas. Tech., 5, 557-568, doi:10.5194/amt-5-557-2012, 2012.

Dodge, M. C.: Combined use of modeling techniques and smog chamber data to derive ozone precursor relationships, in: Proceedings of the International Conference on Photochemical Oxidant Pollution and its Control, 881-889, 1977.

Guenther, A., Karl, T., Harley, P., Wiedinmyer, C., Palmer, P. I., and Geron, C.: Estimates of global terrestrial isoprene emissions using MEGAN (Model of Emissions of Gases and Aerosols from Nature), Atmos. Chem. Phys., 6, 3181-3210, doi:10.5194/acp-63181-2006, 2006.

Hauglustaine, D. A., Hourdin, F., Jourdain, L., Filiberti, M. A., Walters, S., Lamarque, J. F., and Holland, E. A.: Interactive chemistry in the Laboratoire de Météorologie Dynamique general circulation model: description and background tropospheric chemistry evaluation, J. Geophys. Res., 109, D04314, doi:10.1029/2003JD003957, 2004.

Hodzic, A., Madronich, S., Bohn, B., Massie, S., Menut, L., and Wiedinmyer, C.: Wildfire particulate matter in Europe during summer 2003: meso-scale modeling of smoke emissions, transport and radiative effects, Atmos. Chem. Phys., 7, 4043-4064, doi:10.5194/acp-7-4043-2007, 2007.

Hong, S. Y.: Stable boundary layer mixing in a vertical diffusion scheme, The Korea Meteor. Soc., fall conference, Seoul, Korea, 25-26 October 2007.

Hong, S. Y., Noh, Y., and Dudhia, J.: A new vertical diffusion package with an explicit treatment of entrainment processes, Mon. Weather Rev., 134, 2318-2341, 2006.

Honoré, C., Rouil, L., Vautard, R., Beekmann, M., Bessagnet, B., Dufour, A., Elichegaray, C., Flaud, J. M., Malherbe, L., Meleux, F., Menut, L., Martin, D., Peuch, A., Peuch, V. H., and Poisson, N.: Predictability of European air quality: Assessment of 3 years 
of operational forecasts and analyses by the PREV'AIR system, J. Geophys. Res., 113, D04301, doi:10.1029/2007JD008761, 2008.

Horowitz, L. W., Walters, S., Mauzeralles, D. Z., Emmonds, L. K., Rash, P. J., Granier, C., Tie, X., Lamarque, J. F., and Schultz, M. G.: A global simulation of tropospheric ozone and related tracers: Description and evaluation of MOZART, version 2, J. Geophys. Res., 108, 108, 4784, doi:10.1029/2002JD002853, 2003.

Hunova, I., Maly, M., Rezacova, J., and Branis, M.: Association between ambient ozone and health outcomes in Prague, Int. Archives Occupational Environ. Health, 86, 89-97, 2014.

Jenkin, M. E. and Clemitshaw, K. C.: Ozone and other secondary photochemical pollutants: chemical processes governing their formation in the planetary boundary layer, Atmos. Environ., 34, 2499-2527, 2000.

Joseph, J. H., Wiscombe, W. J., and Weinman, J. A.: The deltaEddington approximation for radiative flux transfer, J. Atmos. Sci., 33, 2452-2459, 1976.

Junker, C. and Liousse, C.: A global emission inventory of carbonaceous aerosol from historic records of fossil fuel and biofuel consumption for the period 1860-1997, Atmos. Chem. Phys., 8, 1195-1207, doi:10.5194/acp-8-1195-2008, 2008.

Kain, J. S.: The Kain-Fritsch convective parameterization: An update, J. Appl. Meteor., 43, 170-181, 2004.

Kaiser, J. W., Heil, A., Andreae, M. O., Benedetti, A., Chubarova, N., Jones, L., Morcrette, J.-J., Razinger, M., Schultz, M. G., Suttie, M., and van der Werf, G. R.: Biomass burning emissions estimated with a global fire assimilation system based on observed fire radiative power, Biogeosciences, 9, 527-554, doi:10.5194/bg-9-527-2012, 2012.

Konovalov, I. B., Beekmann, M., Kuznetsova, I. N., Yurova, A., and Zvyagintsev, A. M.: Atmospheric impacts of the 2010 Russian wildfires: integrating modelling and measurements of an extreme air pollution episode in the Moscow region, Atmos. Chem. Phys., 11, 10031-10056, doi:10.5194/acp-11-10031-2011, 2011.

Lau, W. K. M. and Kim, K.-M.: The 2010 Pakistan flood and Russian heat wave: teleconnection of hydrometeorological extremes, J. Hydrometeor., 13, 392-403, 2012.

Lesins, G., Chylek, P., and Lohmann, U.: A study of internal and external mixing scenarios and its effect on aerosol optical properties and direct radiative forcing, J. Geophys. Res., 107, 4094, doi:10.1029/2001JD000973, 2002.

Li, G., Bei, N., Tie, X., and Molina, L. T.: Aerosol effects on the photochemistry in Mexico City during MCMA2006/MILAGRO campaign, Atmos. Chem. Phys., 11, 51695182, doi:10.5194/acp-11-5169-2011, 2011.

Li, J., Wang, Z., Wang, X., Yamaji, K., Takigawa, M., Kanaya, Y., Pochanart, P., Liu, Y., Irie, H., Hu, B., Tanimoto, H., and Akimoto, H.: Impacts of aerosols on summertime tropospheric photolysis frequencies and photochemistry over Central Eastern China, Atmos. Environ., 45, 1817-1829, 2011.

Lou, S., Liao, H., and Zhu, B.: Impacts of aerosols on surface-layer ozone concentrations in China through heterogeneous reactions and changes in photolysis rates, Atmos. Environ., 85, 123-138, 2014.

Madronich, S. and Flocke, S.: The role of solar radiation in atmospheric chemistry, Handbook of Environmental Chemistry, Springer-Verlag, Heidelberg, Germany, 1-26, 1998.
McMeeking, G. R., Morgan, W. T., Flynn, M., Highwood, E. J., Turnbull, K., Haywood, J., and Coe, H.: Black carbon aerosol mixing state, organic aerosols and aerosol optical properties over the United Kingdom, Atmos. Chem. Phys., 11, 9037-9052, doi:10.5194/acp-11-9037-2011, 2011.

Mena-Carrasco, M., Carmichael, G. R., Campbell, J. E., Zimmerman, D., Tang, Y., Adhikary, B., D'allura, A., Molina, L. T., Zavala, M., García, A., Flocke, F., Campos, T., Weinheimer, A. J., Shetter, R., Apel, E., Montzka, D. D., Knapp, D. J., and Zheng, W.: Assessing the regional impacts of Mexico City emissions on air quality and chemistry, Atmos. Chem. Phys., 9, 3731-3743, doi:10.5194/acp-9-3731-2009, 2009.

Menut, L., Bessagnet, B., Khvorostyanov, D., Beekmann, M., Blond, N., Colette, A., Coll, I., Curci, G., Foret, G., Hodzic, A., Mailler, S., Meleux, F., Monge, J.-L., Pison, I., Siour, G., Turquety, S., Valari, M., Vautard, R., and Vivanco, M. G.: CHIMERE 2013: a model for regional atmospheric composition modelling, Geosci. Model Dev., 6, 981-1028, doi:10.5194/gmd6-981-2013, 2013.

Miller, M. R., Shaw, C. A., and Langrish, J. P.: From particles to patients: oxidative stress and the cardiovascular effects of air pollution, Future Cardiology, 8, 577-602, 2012.

Nie, W., Ding, A. J., Xie, Y. N., Xu, Z., Mao, H., Kerminen, V.M., Zheng, L. F., Qi, X. M., Huang, X., Yang, X.-Q., Sun, J. N., Herrmann, E., Petäjä, T., Kulmala, M., and Fu, C. B.: Influence of biomass burning plumes on HONO chemistry in eastern China, Atmos. Chem. Phys., 15, 1147-1159, doi:10.5194/acp-15-11472015, 2015.

Palancar, G. G., Lefer, B. L., Hall, S. R., Shaw, W. J., Corr, C. A., Herndon, S. C., Slusser, J. R., and Madronich, S.: Effect of aerosols and $\mathrm{NO}_{2}$ concentration on ultraviolet actinic flux near Mexico City during MILAGRO: measurements and model calculations, Atmos. Chem. Phys., 13, 1011-1022, doi:10.5194/acp13-1011-2013, 2013.

Péré, J. C., Mallet, M., Bessagnet, B., and Pont, V.: Evidence of the aerosol core-shell mixing state over Europe during the heat wave of summer 2003 by using CHIMERE simulations and AERONET inversions, Geophys. Res. Lett., 36, L09807, doi:10.1029/2009GL037334, 2009.

Péré, J. C., Mallet, M., Pont, V., and Bessagnet, B.: Evaluation of an aerosol optical scheme in the chemistry-transport model CHIMERE, Atmos. Environ., 44, 3688-3699, 2010.

Péré, J. C., Mallet, M., Pont, V., and Bessagnet, B.: Impact of the aerosol direct radiative forcing (ADRF) on the radiative budget, surface heat fluxes and atmospheric dynamics during the heatwave of summer 2003 over Western Europe. A modelling study, J. Geophys. Res., 116, D23119, doi:10.1029/2011JD016240, 2011.

Péré, J. C., Bessagnet, B., Mallet, M., Waquet, F., Chiapello, I., Minvielle, F., Pont, V., and Menut, L.: Direct radiative effect of the Russian wildfires and its impact on air temperature and atmospheric dynamics during August 2010, Atmos. Chem. Phys., 14, 1999-2013, doi:10.5194/acp-14-1999-2014, 2014.

Popovicheva, O., Kistler, M., Kireeva, E., Persiantseva, N., Timofeev, M., Kopeikin, V., and Kasper-Giebl, A.: Physicochemical characterization of smoke aerosol during large-scale wildfires: Extreme event of August 2010 in Moscow, Atmos. Environ., 96, 405-414, 2014. 
Real, E. and Sartelet, K.: Modeling of photolysis rates over Europe: impact on chemical gaseous species and aerosols, Atmos. Chem. Phys., 11, 1711-1727, doi:10.5194/acp-11-1711-2011, 2011.

Saleh, R., Robinson, E. S., Tkacik, D. S., Ahern, A. T., Liu, S., Aiken, A. C., Sullivan, R. C., Presto, A. A., Dubey, M. K., Yokelson, R. J., Donahue, N. M., and Robinson, A. L.: Brownness of organics in aerosols from biomass burning linked to their black carbon content, Nat. Geosci., 7, 647-650, 2014.

Seinfeld, J. H. and Pandis, S. N.: Atmospheric Chemistry and Physics, From air pollution to climate change, WileyInterscience publication, 1998.

Seinfeld, J. H. and Pandis, S. N.: Atmospheric Chemistry and Physics, From air pollution to climate change (2nd Edn.), WileyInterscience publication, 2006.

Slade, J. H. and Knopf, D. A.: Heterogeneous OH oxidation of biomass burning organic aerosol surrogate compounds: assessment of volatilisation products and the role of $\mathrm{OH}$ concentration on the reactive uptake kinetics, Phys. Chem. Chem. Phys., 15, 5898-5915, 2013.

Turquety, S.: The Atmospheric Impact of Wildfires. Fire Phenomena and the Earth System: An Interdisciplinary Guide to Fire Science, Wiley Blackwell, 2013.

Vautard, R., Beekmann, M., Roux, J., and Gombert, D.: Validation of a hybrid forecasting system for the ozone concentrations over the Paris area, Atmos. Environ., 14, 2449-2461, 2001.

Vautard, R., Bessagnet, B., Chin, M., and Menut, L.: On the contribution of natural aeolian sources to particulate matter concentrations in Europe: Testing hypotheses with a modeling approach, Atmos. Environ., 39, 3291-3303, 2005.
Vester, B. P., Ebert, M., Barnert, E. B., Schneider, J., Kandler, K., Schütz, L., and Weinbruch, L.: Composition and mixing state of the urban background aerosol in the Rhein-Main area (Germany), Atmos. Environ., 41, 6102-6115, 2007.

Wai, K. M. and Tanner, P. A.: Variations of aerosol properties due to regional source contributions and impacts on ozone levels: a study in a south China city, Environ. Chem., 7, 359-369, 2010.

Witte, J. C., Douglass, A. R., da Silva, A., Torres, O., Levy, R., and Duncan, B. N.: NASA A-Train and Terra observations of the 2010 Russian wildfires, Atmos. Chem. Phys., 11, 9287-9301, doi:10.5194/acp-11-9287-2011, 2011.

Wu, X., Seigneur, C., and Bergström, R.: Evaluation of a sectional representation of size distributions for calculating aerosol optical properties, J. Geophys. Res., 101, 19277-19283, 1996.

Wu, Z. P. and Wang, Y. P.: Electromagnetic scattering for multilayered spheres: Recursive algorithms, Radio Science, 26, 1393 1401, 1991.

Zhong, M. and Jang, M.: Light absorption coefficient measurement of SOA using a UV-Visible spectrometer connected with an integrating sphere, Atmos. Environ., 45, 4263-4271, 2011.

Zvyagintsev, A. M., Ivanova, N. S., Blyum, O. B., Kotel'nikov, S. N., Kruchenitskii, G. M., Kuznetsova, I. N., and Lapchenko, V. A.: Ozone content over the Russian Federation in the third quarter of 2010, Russian Meteorology and Hydrology, 35, 785789, 2010. 